\title{
学会賞受賞特別寄稿
}

\section{日本の節足動物媒介感染症対応に関する一連の研究 一高病原性鳥インフルエンザとデング熱の国内流行に注目して—}

\author{
澤邊京子* \\ 国立感染症研究所昆虫医科学部（广162-8640 東京都新宿区戸山1丁目23番 1号）
}

（受領：2019年12月26日；登載決定：2020年1月29日）

A series of the studies on countermeasure for arthropod-borne infectious diseases in Japan -Focus on highly pathogenic avian influenza and dengue outbreaks in Japan-

\author{
Kyoko SAWABE* \\ * Corresponding author: sawabe@niid.go.jp \\ Department of Medical Entomology, National Institute of Infectious Diseases, \\ Toyama 1-23-1, Shinjuku-ku, Tokyo 162-8640, Japan
}

(Received: 26 December 2019; Accepted: 29 January 2020)

\begin{abstract}
We have faced a number of outbreaks of arthropod-borne infectious diseases in Japan and aimed to address each case appropriately. Here, I introduce two arthropod-borne infectious diseases caused by flies and mosquitoes, respectively. In 2004, the highly pathogenic avian influenza occurred in Kyoto. The H5N1 influenza A virus was isolated from the blow fly, Calliphora nigribarbis, collected around a poultry farm. Exposure experiments showed that the H5N1 virus survived in C. nigribarbis for at least $24 \mathrm{~h}$. C. nigribarbis was suggested to possibly transport the $\mathrm{H} 5 \mathrm{~N} 1$ virus over a distance of $2 \mathrm{~km}$, which they can access within $24 \mathrm{~h}$. While in 2014,162 autochthonous dengue cases were reported. Dengue virus was isolated from Aedes albopictus collected in the suspected locations of dengue virus infection in Tokyo. Phylogenetic analysis and virus infection experiments revealed that Ae. albopictus was a major dengue vector in Tokyo in 2014. In both cases, we first collected vector arthropods at each outbreak location to understand their biological characteristics and ecological dynamics. We then detected pathogens from the collected arthropods and conducted infection experiments in the laboratory. We can understand that obtaining data from both the field and the laboratory is necessary to confront arthropod-borne infectious diseases.
\end{abstract}

Key words: arthropod-borne diseases, Calliphora nigribarbis, Aedes albopictus, highly pathogenic avian influenza, $\mathrm{H} 5 \mathrm{~N} 1 / \mathrm{A}$ influenza virus, autochthonous dengue outbreaks

\section{はじめに}

近年の地球温暖化や交通網のグローバル化は, 節足動物が 媒介する新興・再興感染症の流行に大きな影響を与え, 世界 各地で深刻な被害をもたらしている. 国内においては, 海外 より新たな病原体やその媒介者（ベクター）が侵入してくる 脅威は増す一方である．例えば，1999年米国ニューヨーク 市で突如として流行したウエストナイル熱はその後北米大陸 全域に拡大し, 米国では毎年2,000名前後の患者が発生して いる. 国内にはアカイエカCulex pipiens pallens Coquillett やヒ トスジシマカAedes albopictus Skuseをはじめとして, ウイル スを媒介し得る蚊が複数種生息すると考えられており, ウ エストナイルウイルスが国内に侵入した場合は大きな劦威 となることが予想されている．また，2014年には合計で 162 名のデング熱の国内感染例が発生したことは記憶に新しい (Arima et al., 2014, Kobayashi and Murota et al., 2018). 翌2015 年にはジカウイルス感染症の流行がブラジルを中心に南北ア
メリカ大陸に拡大し, ヒトスジシマカが主要な媒介種とな るウイルス感染症の輸入例の増加と, 国内流行の可能性が 危惧されるようになった。一方, 八工も公衆衛生上重要な 昆虫であり, 消化器系病原細菌, 原虫, 蠕虫など 130 種類以 上の病原体を機械的に運ぶことが知られるが (Khamesipour et al., 2018），2004年にオオクロバエCalliphora nigribarbis Vollenhoven が H5N1 亜型高病原性鳥インフルエンザウイルス の伝播に関与したと推察された事例が発生した（Sawabe et al., 2006, 2009, 2011). 中国では 2014年以降, H5N1 以外にも H5N6亜型高病原性鳥インフルエンザの流行は家禽にとどま らず，ヒトへの感染例も 16例（うち死亡10例）が報告され, 国内でも2016年にH5N6亜型ウイルス陽性の鳥が発見され た. いずれも中国をはじめとする近隣諸国での流行が国内流 行に密接に関わった事例である.

一方で, 従来から国内に分布, 生息している在来の病原 体あるいはべクターによる被害の拡大も懸念されるところ である。例えば, ダニ媒介脳炎は, 国内では 1993 年に北海 
道で初めて感染例が報告された. 直後の疫学調査でマダニ からウイルスが分離され，野鼠とイヌに抗体陽性の個体が いることも確認された（Takashima et al., 1997）。2016年7月 には 23 年ぶりに国内 2 例目となる患者が北海道から報告さ れ，その後も毎年患者発生がある. 2013年には重症熱性血 小板減少症候群（SFTS）の患者が国内で初めて報告された が (Takahashi et al., 2014)，それ以降も西日本を中心に患者 が発生し, 約 $20 \%$ の高い致死率を示すことで高い関心を呼ん でいる.ベクターであるダニの移動は宿主動物となる野生動 物の移動に影響を受けるため, SFTSの流行域が西日本から 東に拡大傾向にあることに野生動物の生息域拡大が大きく 関わっていると考えられている. また，ヒトジラミPediculus humanus Linnaeusが媒介する塹壕熱も再興感染症として近年 注目されている。塹壕熱は, 第一次世界大戦や第二次世界大 戦の際に, 塹壕内で戦った多くの兵士が感染した. その後は 大きな流行は見られなかったが, 1990 年代に入り途上国の 非衛生的な施設等で, さらに先進国でも社会問題になってき た路上生活者の増加に伴い, 都市部を中心にコロモジラミの 散発的な流行が見られるようになった. 我が国でも路上生活 者の数は年々増加し, さらにネットカフェや簡易宿泊施設等 でのコロモジラミの被害が報告されるようになった．東京， 大阪等の都市部のコロモジラミから塹壕熱の原因菌である Bartonella quintana 遺伝子が検出され, 静かに都市域に広がっ ていることが指摘された（佐々木ら，2010；沢辺ら，2010）.

このように, 近年, わが国における節足動物が媒介する新 興・再興感染症は頻発している. 我々はこれまでにいくつも の節足動物媒介感染症の流行に直面し, その都度適切な対策 を実施するよう努めてきた，ここでは, 衛生動物学の分野で 重要なべクターであるハエと蚊に注目し，それらが直接・ 間接的に感染症の流行に関わった $2 つ の$ 事例, 2004年の高病 原性鳥インフルエンザの流行拡大（Sawabe et al., 2006, 2009, 2011）と2014年のデング熱の国内流行（Tanikawa et al., 2015; Tsuda et al., 2016; Kobayashi and Murota et al., 2018）に対応した 一連の調査・研究の成果を紹介する.

\section{1. ハエがもたらす感染症：腸管出血性大腸菌感染症と鳥イ ンフルエンザ}

八工は公衆衛生上重要な昆虫であり, 消化器系病原細菌, 原虫, 蠕虫など 130 種類以上とも言われる病原体を機械的に 運ぶことが知られている（Khamesipour et al., 2018）。その伝 播方法は蚊やマダニなどの吸血昆虫に多く見られる生物学的 伝播ではなく, 取り込んだ病原体を運ぶ機械的伝播である. トイレが普及していない開発途上国などでは，糞食性である イエバエMusca domestica Linnaeusから赤痢菌が検出されるこ とも少なくない（Qureshi et al., 2014, George et al., 2015). わ が国でも 1996年に腸管出血性大腸菌Escherichia coli O157（以 下O157 と記す）による集団食中毒が全国規模で発生した. その後行われた全国調査で, 採集されたイエバエから 0157 が検出・分離され，イエバエの関与が強く示唆された（安 居院, 1998; Iwasa et al., 1999; Kobayashi et al., 1999; Sasaki et al., 2000).

2003 年 12 月山口県阿東町の養鷄場での発生を契機に, 国 内では79年ぶりとなる高病原性鳥インフルエンザの流行が 始まった（岡部，2004）。翌2004年3月までに大分県九重町 では少数のチャボが, 京都府丹波町ではニワトリが大量に死

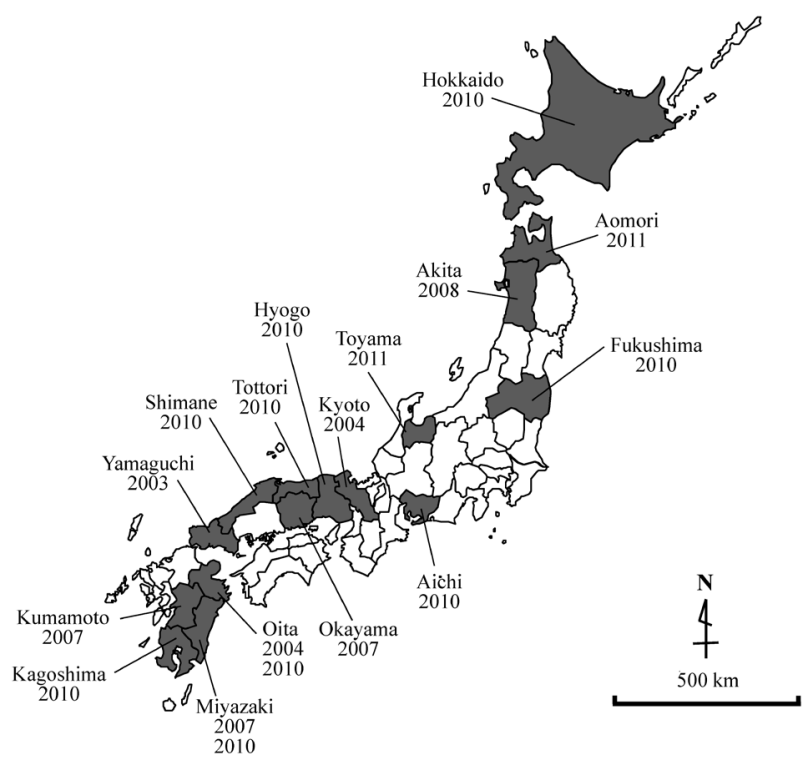

Fig. 1. The avian influenza outbreaks caused by H5N1 subtype occurred in Japan since 2003 reported by prefecture. This map shows prefectures and years when avian influenza outbreaks occurred.

亡し，畜産業界ならびに消費社会に大きな波紋を呼んだ。い ずれも H5N1亜型ウイルスの感染による流行であった（Mase et al., 2005). Fig. 1に示すように, その後も H5N1亜型インフ ルエンザウイルスの家禽や水禽での感染事例が相次ぎ, 続 く2005年と 2006 年の夏には, 茨城・埼玉両県下の養鶏場で 弱毒タイプの H5N2 亜型ウイルスが流行し, 2007年1月には, 宮崎県と岡山県で再びH5N1 亜型ウイルスによる高病原性鳥 インフルエンザが再燃した（Sawabe et al., 2011）。この H5N1 亜型インフルエンザウイルスはアジア諸国において水禽およ び家禽類の間でしばしば流行し，甚大な経済的損失をもたら している.ほとんどの鳥インフルエンザウイルスは人には感 染しないが, H5N1亜型ウイルスのように, 一部の亜型のウ イルスは人に直接感染し, 致命的な症状を引き起こすこと が 1997年香港での感染症例（6人死亡）以降知られるように なった（Subbarao et al., 1998; Yuen et al., 1998).

これらの事例を経験したことで，2011年3月に起きた東日 本大震災被災地での八工類の大量発生に伴う感染症の流行が 危惧された（林・澤辺，2016）。

\section{高病原性鳥インフルエンザ発生地におけるハエ類の調査}

2004年 2-3月, 高病原性鳥インフルエンザが発生した京都 府丹波町周辺では, ウイルスの確認が行われた直後から野鳥 類に対するウイルス污染調查が行われ, 発生農場 Aから半径 $30 \mathrm{~km}$ の移動制限区域内で防疫措置期間中にカラスの死亡個 体が多数発見された。 このうち京都府の 7 羽, 大阪府の 2 羽 から H5N1亜型ウイルスが検出されたが，その他の野生動物 からは検出されなかった (Mase et al., 2005). 国内では約79 年ぶりに発生したこの鳥インフルエンザの流行は, 2003年 12月から3月まで続いたことから, 冬季に活動性が高まる八 工類, 特にオオクロバエとケブカクロバエ Aldrichina grahami (Aldrich) の関与が強く疑われた. 両クロバエは, 夏季に 鶏舎周辺で行われた調查（2005年6月茨城県小川町で $\mathrm{H} 5 \mathrm{~N} 2$ 亜型鳥インフルエンザが流行した際に実施）で多く採集さ 


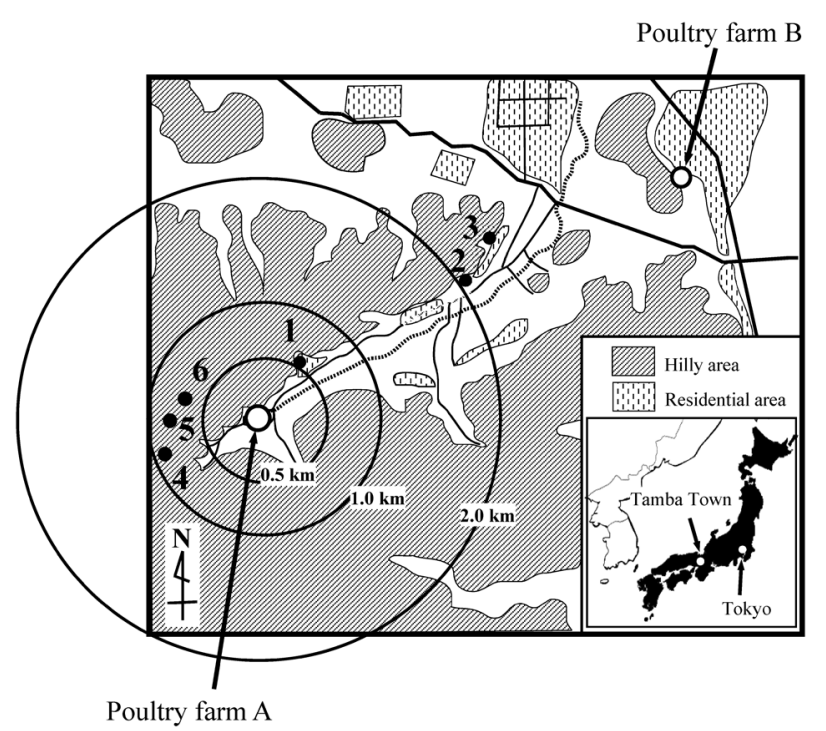

Fig. 2. Localities in Tamba Town from which flies used in this study were obtained. This figure was modified from Sawabe et al. (2006).

れたヒロズキンバエ Phaenicia sericata Meigen, オオイエバエ Muscina stabulans (Fallen)，イエバエ等，主に夏に活動する 八工類（倉橋ら，未発表）とは異なる冬季活動性の種類の八 エである.

著者らは，国内 2 例目となった大分県九重町で 2004 年 2 月 24-25日，続く 3 例目となった京都府丹波町で同年3月 9-12 日に，鳥インフルエンザが発生した農場 Aから 600-2,250 m に位置する6地点（Fig. 2, 地点 1-6）で魚肉（鰯）べイトを 用いてハ工類の採集を行った. 京都府丹波町では, 約 19 時 間半の総採集時間で合計926頭のハエが採集され，最も採集 数の多かった地点 1（養鶏場より東方向に $600 \mathrm{~m}$ の南側斜面 に位置する場所）では，3時間で 403 頭が採集された（1時間 当り 134 個体). 6 地点の平均採集数は 48 頭 /時間であった. ここでは結果は省略したが, 農場 Aから距離が離れるにつれ 八工類の採集数が減少したことは, 農場 Aがハ工類の主要な 生息場所であったことを示唆していた.

地点 1 で採集された 403 頭のハ工類のうち 181 頭のハエの 種同定を行った結果，オオクロバエ（72頭，39.8\%）とケブ カクロバエ (73頭，40.3\%）で全体の約 $80 \%$ を占め，これに オオイエバエ（29頭，16\%）を加えると $96 \%$ に達すること が判明した（Table 1). チャボでの感染が確認された大分県 九重町で行った調査でも，才オクロバエとケブカクロバエの 比率は, 本結果とほぼ同様であったことから, この2種類が 冬季の代表的なハエであることが示唆された。

\section{捕集したハ工類からのウイルス検出}

農場 $\mathrm{A}$ 周辺の6地点で採集したクロバエから消化器官（そ 囊と腸管）を摘出し, 各種 20 頭から個体別に摘出した消化 器官をまとめて 1 プールとし，八工乳剂を作製した。 八工乳 剂から抽出したRNAを用いて RT-PCR およびsemi nested-PCR を行い, インフルエンザウイルスの型 (A 型, B型, C型) と亜型（H1-H15 亜型）を特定するためのマトリックスタン パク（M）とへマグルチニン（HA）の両タンパク遺伝子の 検出を試みた。農場 $\mathrm{A}$ から約 $600 \mathrm{~m}$ 東の南側斜面に位置する 地点1（Fig. 2）で採集されたオオクロバエとケブカクロバエ
Table 1. Species composition of flies collected at site 1 of Tamba Town.

\begin{tabular}{lcc}
\hline \hline \multicolumn{1}{c}{ Species } & $\begin{array}{c}\text { No. } \\
\text { collected }\end{array}$ & $\begin{array}{c}\text { Proportion } \\
(\%)\end{array}$ \\
\hline Aldrichina grahami (Aldrich) & 73 & 40.3 \\
Calliphora nigribarbis Vollenhoven & 72 & 39.8 \\
Muscina stabulans (Falle'n) & 29 & 16.0 \\
Triceratopyga calliphoroides Rohdendorf & 2 & 1.1 \\
Muscina angustifrons (Loew) & 2 & 1.1 \\
Muscina pascuorum (Falle'n) & 1 & 0.6 \\
Lucilia porphyrina (Walker) & 1 & 0.6 \\
Phaenicia sericata Meigen & 1 & 0.5 \\
Total & 181 & 100 \\
\hline
\end{tabular}

This table was from Sawabe et al. (2006).

Table 2. Detection of H5 influenza A virus from blow flies collected at Tamba Town in 2004.

\begin{tabular}{clcccc}
\hline \hline Site* & \multicolumn{1}{c}{ Species } & $n$ & Crop & Gut & $\begin{array}{c}\text { No. positive } \\
\text { flies (\%) }\end{array}$ \\
\hline 1 & C. nigribarbis & 10 & 1 & 2 & $2(20)$ \\
1 & A. grahami & 10 & 0 & 2 & $2(20)$ \\
6 & C. nigribarbis & 10 & 2 & 3 & $3(30)$ \\
6 & A. grahami & 10 & 0 & 0 & 0 \\
2 & C. nigribarbis & 10 & 1 & 0 & $1(10)$ \\
& A. grahami & 10 & 0 & 0 & 0 \\
\hline
\end{tabular}

* See Figure 2 for site 1, 2, and 6 details.

${ }^{\dagger}$ Virus gene-positive flies were detected by RT-PCR results from crop and gut specimens. This table was from Sawabe et al. (2006).

の各 2 プールのすべてから $\mathrm{M}$ および $\mathrm{HA}$ 遺伝子断片が検出さ れた. しかし, 同地点で採集されたオオイエバエとモモグロ オオイエバエMuscina angustifrons（Loew）からは，いずれの 遺伝子も検出されなかった. そのHA遺伝子のアミノ酸配列 には, 病原性の強さに関わるとされる開裂部位が認められ, 本ウイルスが強毒タイプであると推察された。

次いで, 農場 A から 600-700 m 付近に位置する地点 1 と地 点6（Fig. 2）および約 $2 \mathrm{~km}$ 離れた地点2（Fig. 2）で採集され たオオクロバエとケブカクロバエの各 10 頭からそ囊と腸管 をそれぞれ摘出し，個体別にRT-PCRおよびsemi nested-PCR により $\mathrm{M}$ および $\mathrm{HA}$ 遺伝子断片の検出を試みた。 その結果, オオクロバエのウイルス遺伝子保有率は 10-30\% と高率で, 地点 1 と地点 6 で $20-30 \%$, 約 $2 \mathrm{~km}$ 離れた地点 2 でもオオクロ バエの約 $10 \%$ が本ウイルスの遺伝子を保有していたことが明 らかになった. また, ケブカクロバエにおいても, 地点 1 で 採集された個体の $20 \%$ がウイルス遺伝子を保有していたこと が明らかになった（Table 2)。ここでインフルエンザウイル ス遺伝子陽性と判定されたオオクロバエの消化器官の乳剂を 個別に発育鷄卵に接種し， ウイルス分離を試みたところ， ウ イルス遺伝子陽性であった 10 頭のうち 2 頭のハ工乳剂からイ ンフルエンザウイルスが分離された．分離株の HA，ノイラ ミニダーゼ（NA）およびM遺伝子の全塩基配列を解析した 結果, 本ウイルスが $\mathrm{H} 5 \mathrm{~N} 1$ 亜型高病原性 A 型インフルエンザ ウイルスであることが明らかになった，また，本ウイルスは 農場 $\mathrm{A}$ で死亡した鷄から分離された H5N1亜型ウイルス株と 
の間に 99\%以上の高い塩基相同性を示したことから，両者が 同一ウイルスであると判定された。 丹波町において鳥インフ ルエンザが発生した当時, 発生農場周辺では感染性のあるウ イルスを体内に保有したクロバエが多数飛翔しており, 計算 上はオオクロバエの約 $5 \%$ が保有していたと推定された, こ のウイルスが次の発生農場への感染源となった可能性が強く 示唆された（Sawabe et al., 2006）.

\section{オオクロバエとケブカクロバエ}

丹波町でインフルエンザウイルスを保有していたオオクロ バエとケブカクロバエは, いずれも日本, 韓国, 中国, 台湾 などの東アジア地域に分布し，国内では，積雪量が多くない 関東以西では秋から春にかけて平野部の山脚部や都市の住宅 地などで普通に見られる，いわゆる冬に繁殖期を迎えるハ工 である.わが国におけるオオクロバエの生活史（倉橋・末 永, 1997）によると, 成虫は秋から春にかけて温暖な地方で 動物の死体や家畜等の排泄物などを活発に摂食し産卵活動を 行い, 鶏舎や畜舎にも侵入する. 初春に現れる新成虫は初夏 には高地など冷涼地へ移動しそこで夏を越す，そのため，低 地からは一旦姿を消すが, 秋に再び低地に現れて繁殖を開始 する. 丹波町で鳥インフルエンザの流行が起こった 12 月か ら3月にかけての冬季は才オクロバエの繁殖期に相当してい たと考えられる. また, オオクロバエの国内での移動と分散 を調査した mark-release-recapture 実験から，このハエは1日 に少なくとも2-3kmの飛翔は容易であることが示唆されて いる（Tsuda et al., 2009）. 鳥インフルエンザが流行した丹波 町の 2 軒の養鶏場はわずかに $4 \mathrm{~km}$ しか離れておらず, 実際に 両鶏舎のほぼ中間地点である $2 \mathrm{~km}$ を過ぎた場所（地点 $3, \mathrm{Fig}$. 2）でもウイルス遺伝子陽性のオオクロバエが採集された.

この2種類のクロバエは, 八工類の中では大型種に区分さ れ，いずれも動物の死体や排泄物を好んで摂食する習性が ある.インフルエンザに感染したニワトリの粪中にはウイ ルスが大量に排泄され，次の感染源となることから，丹波 町の発生養鷄場周辺のクロバエ類がニワトリの翼と一緒に ウイルスを取り込んだ可能性は高い. Table 2で示されたよ うに，才オクロバエのウイルス遺伝子陽性率はケブカクロ バエよりも高かった．これは体のサイズ（オオクロバエの 体長：11-15 mm，ケブカクロバエ8-13 mm，才オイエバエ: 7-9.5 mm)，つまり，そ囊や腸管などに摂取されるウイルス 量の差によってもたらされたと考えられる．食慨をより多く 摂食できる種類の八エは, 排泄物や污物に含まれるウイルス をも多く取り込むことができるからである．また，才オクロ バエの寿命は長く, 繁殖能力にも優れている. 成虫の活動す る長い期間に何度でも摂食することができると考えられる。

\section{ハエ体内でのインフルエンザウイルスの生存期間}

オオクロバエに H5N1インフルエンザウイルスを摂食さ せ，八工体内での生存期間を推定した（Table 3).オオクロ バエの雌成虫に, ケージ $(20 \times 20 \times 20 \mathrm{~cm})$ 内で約 3 時間, 脱 脂綿に浸み込ませた $10^{8} \mathrm{EID}_{50} / \mathrm{mL}$ の H5N1 亜型ウイルス液 (A/ duck/Hyogo/35/01, 神戸市環境保健研究所, 秋吉京子氏より 分与）を摂食させ，その後3-72時間までは継時的に，およ び14日後にそれぞれ3頭ずつハエを解剖し, (1)そ囊, (2)消化 器官を摘出し, (3)糞と吐出物, (4)ウイルスを浸み込ませた脱 脂綿からそれぞれウイルス乳剂を調整した。 その乳剂を発育
鶏卵接種によりウイルス分離を試みると同時に, MDCK細 胞（犬の腎臓由来細胞）培養系を用いてウイルス力価（感 染増殖能のあるウイルス粒子の数) を測定した. また, RTPCRにより (1)-(4)の各検体からウイルス遺伝子の検出も行っ た. その結果, ウイルス液を摂食したオオクロバエは, その 実験期間である 14 日間はほぼすべての検体からウイルス遺 伝子は検出されたが, 力価のあるウイルスは摂食後 24 時間 までは八工体内で維持されることが明らかになった（Table 3). MDCK細胞培養系においてもほぼ同様の結果であった が，糞や吐出物の中には 3 頭中 1 頭ではあったが，48時間後 もウイルスカ価が測定できたことから，48時間ウイルスが クロバエの体内で保持される可能性があることも示唆され た.これらの結果から, オオクロバエ体内でインフルエンザ ウイルスは増殖せず，その力価は低下する傾向にあったが, 少なくとも 24-48時間はその感染性は維持されており, その 間は次の鶏への感染源となる得る可能性があると推察された (Sawabe et al., 2009).

\section{インフルエンザウイルスの運搬者としてのオオクロバエ}

上述したように, オオクロバエの生物学的特徵を考慮する と, 本種がインフルエンザウイルスを伝播する可能性は高い と考えられた. オオクロバエの特徴は以下のようにまとめら れる.

(1)オオクロバエは冬季に活動するハエであり，国内での高 病原性鳥インフルエンザが流行する時期と概ね一致する. (2) 成虫は動物の糞便や死体などを好んで食べるため, 鳥インフ ルエンザで死亡したニワトリの死体や排泄物に集まったと思 われる. (3)才オクロバエは大型のハエであるため, その食餌 がウイルスに污染されていれば，污染された排泄物等と同時 にウイルスも大量に取り込む可能性は高い. (4)オオクロバエ の成虫の寿命は長く, その間の食䬲量も多く, ウイルスを取 り込む量も回数も多いと考えられる. (5)移動能力に優れ, 24 時間内で少なくとも半径 $2-3 \mathrm{~km}$ に存在する近隣の鶏舎間を 移動することは容易である.このようなクロバエ類の生物学 的特徴, 実際にインフルエンザウイルスがこれらクロバエ類 から検出された事実, ならびに実験室内でのオオクロバエへ の摂食実験の結果を総合すると, クロバエ類がカモや渡り鳥 の飛来地から養鵎場へ, あるいは近隣の鶏舎間を飛び回り, インフルエンザウイルスを機械的に伝播する可能性は高いと 考えられる.

\section{鳥インフルエンザウイルス流行の疫学}

京都府丹波町の鳥インフルエンザ発生農場の死亡鵎から分 離された H5N1 亜型ウイルスの起源は, 1996年中国広東省の ガチョウ農場で検出されたウイルスにまで遡る（Mase et al., 2005）。このウイルスが 2003 年に中国山東省, 同年 12 月に韓 国で大流行を引き起こし，その後日本へ侵入したと考えられ ており, 本ウイルスが海外から侵入してきたことは事実であ る. ウイルスに感染したカモ類などの渡り鳥が海外よりウイ ルスを持ち込んだ可能性が高いが, 海外より飛来する動物は 渡り鳥だけではなく, 晚秋に大陸から長距離飛翔してくるク ロバエ類の存在も示唆されている（倉橋・未永, 1997).

オオクロバエの国内での繁殖期に当たる秋から春にかけ て北部九州の渡り鳥の飛来地周辺において調査したところ, 2006年11月下旬に佐賀県で採集されたオオクロバエから水 
Table 3. Diagnostic results of H5N1 influenza A viruses from crop, intestine and feces and vomit matters of a blow fly after experimental exposure to the virus solution.

\begin{tabular}{|c|c|c|c|c|c|c|c|c|c|c|c|c|c|c|}
\hline \multirow{2}{*}{\multicolumn{2}{|c|}{ Postexposure }} & \multirow{3}{*}{$\begin{array}{c}\text { Replicate } \\
1\end{array}$} & \multicolumn{3}{|c|}{ Crop } & \multicolumn{3}{|c|}{ Intestine } & \multicolumn{3}{|c|}{ Feces and vomit matters } & \multicolumn{3}{|c|}{ Virus-exposed cotton } \\
\hline & & & \multirow{2}{*}{$\frac{\text { VI }}{+}$} & \multirow{2}{*}{$\begin{array}{r}\mathrm{TCID}_{50} \\
3.50\end{array}$} & \multirow{2}{*}{$\begin{array}{c}\text { PCRs } \\
+\end{array}$} & \multirow{2}{*}{$\frac{\text { VI }}{+}$} & \multirow{2}{*}{$\frac{\mathrm{TCID}_{50}}{3.50}$} & \multirow{2}{*}{$\begin{array}{c}\text { PCRs } \\
+\end{array}$} & \multirow[t]{2}{*}{ VI } & \multirow[t]{2}{*}{$\mathrm{TCID}_{50}$} & \multirow[t]{2}{*}{ PCRs } & \multirow{2}{*}{$\frac{\text { VI }}{\text { NT }}$} & \multirow{2}{*}{$\frac{\operatorname{TCID}_{50}{ }^{a}}{5.00}$} & \multirow{2}{*}{$\frac{\text { PCRs }}{+}$} \\
\hline $20^{\circ} \mathrm{C}$ & $3 \mathrm{~h}$ & & & & & & & & & & & & & \\
\hline & & 2 & + & 3.33 & + & + & 4.00 & + & & & & & & \\
\hline & & 3 & + & 1.83 & + & + & 0.50 & + & & & & & & \\
\hline & & 4 & + & 4.60 & + & + & 3.50 & + & & & & & & \\
\hline & & 5 & + & 2.60 & + & + & 3.00 & + & & & & & & \\
\hline & & 6 & + & 1.67 & + & + & 1.67 & + & & & & & & \\
\hline & & 7 & + & $<0.50$ & + & + & $<0.50$ & + & & & & & & \\
\hline & & 8 & + & 4.63 & + & + & 3.50 & + & & & & & & \\
\hline & & 9 & + & 3.00 & + & + & 3.63 & + & & & & & & \\
\hline & & 10 & + & $<0.50$ & + & + & $<0.50$ & + & & & & & & \\
\hline & $6 \mathrm{~h}$ & 1 & + & $<0.50$ & + & + & 3.50 & + & - & NT & + & NT & 4.50 & + \\
\hline & & 2 & + & $<0.50$ & + & + & 1.50 & + & - & NT & + & & & \\
\hline & & 3 & - & $<0.50$ & + & - & $<0.50$ & + & - & NT & + & & & \\
\hline & $9 \mathrm{~h}$ & 1 & + & 1.00 & + & + & 1.00 & + & - & NT & + & NT & 5.60 & + \\
\hline & & 2 & + & $<0.50$ & + & + & $<0.50$ & + & - & NT & + & & & \\
\hline & & 3 & - & $<0.50$ & + & - & $<0.50$ & + & - & NT & + & & & \\
\hline & $24 \mathrm{~h}$ & 1 & - & $<0.50$ & + & - & $<0.50$ & + & - & NT & + & NT & 4.67 & + \\
\hline & & 2 & - & $<0.50$ & + & - & $<0.50$ & + & - & NT & + & & & \\
\hline & & 3 & + & 1.67 & + & + & $<0.50$ & + & - & NT & + & & & \\
\hline & $48 \mathrm{~h}$ & 1 & - & NT & + & - & NT & + & + & $<0.50$ & + & NT & 4.83 & + \\
\hline & & 2 & - & NT & + & - & NT & + & - & NT & + & & & \\
\hline & & 3 & - & NT & + & - & NT & + & - & NT & + & & & \\
\hline & $14 \mathrm{~d}$ & 1 & - & NT & + & - & NT & + & - & NT & + & NT & $<0.50$ & + \\
\hline & & 2 & - & NT & + & - & NT & + & - & NT & + & & & \\
\hline & & 3 & - & NT & + & - & NT & + & - & NT & + & & & \\
\hline $10^{\circ} \mathrm{C}$ & $14 \mathrm{~d}$ & 1 & - & NT & + & - & NT & + & - & NT & + & NT & $<0.50$ & + \\
\hline & & 2 & - & NT & + & - & NT & + & - & NT & + & & & \\
\hline & & 3 & - & NT & + & - & NT & + & - & NT & + & & & \\
\hline
\end{tabular}

VI: virus isolation using embryonated chicken eggs, $\mathrm{TCID}_{50}$ : virus titers $\left(\log _{10} \mathrm{TCID}_{50} / 0.05 \mathrm{~mL}\right)$ were calculated by the inoculation onto MDCK cells, PCRs: RT-PCR performed with specific primers for the HA and M genes and followed by a nested PCR with primers for the HA gene, NT: not tested.

${ }^{a}$ The average of two times of the virus titration.

This table was modified from Sawabe et al. (2009).

禽類由来の $\mathrm{H} 5$ 亜型以外の $\mathrm{A}$ 型インフルエンザウイルスが検 出された (Sawabe et al., 2011). オオクロバエが水禽類と接触 し, その排泄物からウイルスを摂取したであろうことを示唆 している. その渡り鳥の飛来地から鳥インフルエンザ発生農 場へは, ウイルスはどのようにして運ばれたのだろうか?カ モ以外の野鳥やネズミが養鷄場にウイルスを持ち込む可能性 があると推察されたが, 発生農場の多くは防鳥ネットを使用 しており閉鎖型の鶏舎も増えてきたことから，これらの動物 が彩息と接触する可能性は極めて低いと思われる. 一方, 養䊿 場に飛来したオオクロバエが防鳥ネットをかいくぐって鶏舎 内部に侵入することは容易であることは言うまでもない．ま た，ニワトリは近くを飛び回る八エを容易に捕まえて，生き たままでも食べる習性があるため, もしそのハエが感染力の あるウイルスを保有していた場合, ニワトリがウイルスに感 染する可能性は高いと思われる.

国内においては，冬季に活動するクロバエ類の鳥インフル エンザ伝播への関与が危惧されるが，アジア諸国では，いく
つかの亜型のインフルエンザウイルスが鳥と人の両者に公衆 衛生上深刻な問題をもたらすことが知られている。これらの 国々の多くは亜熱帯から熱帯に位置し，一年を通して様々な 種類の八工類が絶えず活動しているため, 常に鳥インフルエ ンザが発生する可能性が高いと推察される. 事実, トルコに おいては，イエバエにH9N2インフルエンザウイルスを摂食 させ，八エの体表で 24 時間，体内で96時間維持されること が実証され（Salamatian et al., 2019），養鵎場内での拡散に警 鐘を鳴らすことになった。

\section{高病原性鳥インフルエンザ発生の防止対策}

2004年の鳥インフルエンザ流行に際しては, 残念ながら 八工類を意識した対策は取られなかった，なぜなら，その感 染経路や感染方法などが十分に解明できなかったからであ る. 当時の農林水産省のホームページには, ウイルスの侵入 経路について以下のような記載があった. (1)ウイルスに感染 している鶏を海外より導入した. (2)ウイルスに污染された器 
材・車両・卵ケースなどを使用した。 (3)人の衣服・手・長鞉 などを介してウイルスが持ち込まれた. (4)野鳥が出入りでき る鶏舎や屋外養鶏場では, 感染した野鳥がウイルスを持ち込 んだ可能性がある。これに則り, 各自治体はペストコント ロール協会と協力して, 出入りする車輛に消石灰を散布し, 作業者や従業員の防護服や長靴等を消毒した。 各養鷄場では 防鳥ネット等の強化で野鳥やネズミの侵入阻止に務めるとと もに, 飼料タンク周辺や鶏舎内の清潔に留意し, 鶏糞の処理 を徹底した. 現在もほぼ同様の対応がなされていると聞く. しかし, 様々な病原体の運搬者である八工類が, 深刻な感染 症にも関わる可能性があることを考えると, 鳥インフルエン ザの対策に八工類の駆除も加えることが望ましい.しかし， 実際には, 環境整備だけでは対処できない場合も多く, 殺虫 剂を使う防除が主な手段となることが多い，例えば，鶏穓 に昆虫成長制御剂（IGR）を散布し幼虫対策を行う。鶏舎に よってはこれに加え成虫対策として, ベイト（食毒）剂の設 置, または八エがよく止まる壁面に処理し殺虫効果に残効性 のある殺虫剂残留処理（ペイント率の残留噴霧）を併用する なども効果的であるとしている（冨田・小林，2007）.

国内に抽，イエバエの各種殺虫剤に対する抵抗性の発 達が深刻な問題となって久しいが, オオクロバエに扎いて は, フェニトロチオンやペルメトリン等のピレスロイド剤に 対して依然として高い感受性を示すことが報告されている (Komagata et al., 2007). 事実, その後に発生した東日本大震 災の被災地におけるクロバエ類の駆除に，ピレスロイド系殺 虫剂の散布が効果を発揮している. 2011年3月に東北地方の 湾岸地域を襲った激甚津波は水産加工場の冷凍庫を破壊し, 散乱し放置された腐敗魚介類や打ち上げられた漁網や瓦礫等 が発生源となり, 主にクロバエ科のハエが大量に発生した. 同時に発生していたイエバエにおけるフェニトロチオン乳剤 ならびにエトフェンプロックス乳刘散布の効果はクロバエよ りも低かったものの, 散布 24 時間後のクロバエの生息密度 は80-90\%減少したことが明らかになった（田原ら，2012）.

\section{2. 蚊がもたらす感染症}

蚊は世界中に約 3,000 種, 日本国内にはそのうち約 110 種 が記録されているが, 病原体の媒介に関与する種類はその一 部である.1897年にマラリア原虫が蚊によってヒトに媒介 されることが実証されて以降, 蚊が多くの感染症の伝播に関 わり, 特に多くの節足動物媒介性ウイルス（アルボウイル ス）を媒介することが明らかになった。例えば，1906年に デング熱が蚊媒介性であることが証明され，1935年に日本 脳炎ウイルスが分離された. 次いで1937年にウエストナイ ルウイルスが発見され, ジカウイルスが1947年, チクング ニアウイルスが1953年, それぞれアフリカ大陸からの発見 が相次いだ. その中でもデング熱の流行地域と患者数は, こ こ数十年間で劇的に増加し, 再興感染症の中でもマラリアと 共に世界的にもっとも重要な疾患の一つとして世界保健機構 （WHO）が監視している感染症である. 年間約 4 億人がデン グ熱を, 約 25 万人がデング出血熱を発症し, そのうちの約 1 割（約2万人）が死亡している（WHO, 2019）.

国内では, 1942年の夏に東南アジアから帰国した船員に よってデング熱が持ち込まれ，ヒトスジシマカを媒介蚊とし てその後の 3 年間で 20 万人以上ともいわれる大流行が記録さ れている. それ以降はすべて輸入症例であったが, 2010年
以降の症例数は増加傾向にある. 249 例の輸入症例が報告さ れた2013年には，8月中旬から下旬にかけて日本国内を旅行 したドイツ人が, 成田空港から直行便で帰国後の9月 3 日に 発熱し，その後デング熱と診断され（Schmidt-Chanasit et al., 2014）, 国内で感染したことが強く疑われた事例として報告 された. 翌2014年 8 月 27 日には, 約 70 年ぶりのデング熱国 内感染が発生した。東京都内を中心に合計で 162 名の患者が 報告された年である（Kutsuna et al., 2014; Arima et al., 2014）. 幸い, 翌2015年に国内感染例は発生しなかったが, 輸入症 例数はさらに増加し，2019年は過去最高の患者数 461 名が報 告された。同年9-10月には，国内感染したと疑われる症例 が沖縄県, 京都府と奈良県から相次いで報告された。 日本は すでにデング熱が毎年流行しても不思議ではない国になっ ていると考えざるを得ない，事実，WHOは，日本はもとよ り, 同じ温帯地域にあるヨーロッパ諸国でもデング熱が流行 する可能性があるとしている（WHO, 2019）.

\section{ヒトスジシマカ}

ヒトスジシマカは, 世界の熱帯から温帯地域に広く分布 し, 日本では, 北海道を除く国内のほとんどの地域の都市部 によく見られる. 背中（中胸背板）にある一本の白い筋が大 きな特徴である. 成虫は, 民家の庭, 公園, 墓地などの茂み に潜み, 待ち伏せして吸血する. 主に屋外で活動し, 朝方か ら夕方まで激しく吸血する.

ヒトスジシマカの卵は乾燥に強く, 数ヶ月の乾燥に遭 遇しても，いったん水に浸ると孵化してくる. 1984年に 米国ヒューストンで初めてヒトスジシマカの定着が確認 された際, 日本から輸出された古タイヤの内側に乾燥卵 が付着していたことが後で明らかになった（Springer and Wuithiranyagool, 1986). その後, 米国から輸出された古タイ ヤを介してヒトスジシマカがイタリアに侵入し，チクングニ ア熱の流行に関与したと考えられている（Dalla et al., 1994）. ヒトスジシマカの幼虫は比較的小さな容器, 住宅地では雨水 マス, 植木鉢やプランターの水受け血, 庭先に置き忘れたバ ケツや劽, コンビニ弁当などのプラスチック容器, 古タイヤ などによく発生するため, 個人的な対策は取りやすいが, 幼 虫対策だけでは成虫の数は劇的には減らないのが現実であ る. 幼虫の生息地は, 年平均気温が $11^{\circ} \mathrm{C}$ 以上の地域とよく 一致しており, 温暖化の影響等により，その分布域は徐々に 北上している（Kobayashi et al., 2014）．その後の調査で, 2015 年に本州北端の青森市に侵入し, 翌2016年に定着が確認さ れた（沢辺ら，2017）。

\section{デング熱国内感染推定感染地における媒介蚊調査}

2014年 8 月 27 日, 約 70年ぶりにデング熱の国内感染例が 発生した（Arima et al., 2014; Kutsuna et al., 2015). 国内外から 多くの観光客が集まる代々木公園の渋谷門周辺でダンスの練 習中に蚊に刺されたらしいことが後に報道された. 最終的 に東京都内の公園で感染したと推測される症例 147名を中心 に, 合計 162 名の国内感染例が報告されたことが 10 月 31 日 付けの厚生労働省の発表で明らかになった. 患者からの申告 で, 都内のいくつかの公園や住宅地で蚊に刺されたことが明 らかになったため, 著者らは, その推定感染地とされた都 内の公園の, それぞれ複数か所を選定し媒介蚊調査を行っ た（Tsuda et al., 2016）（Fig. 3）.8月28日に東京都が殺虫剂 


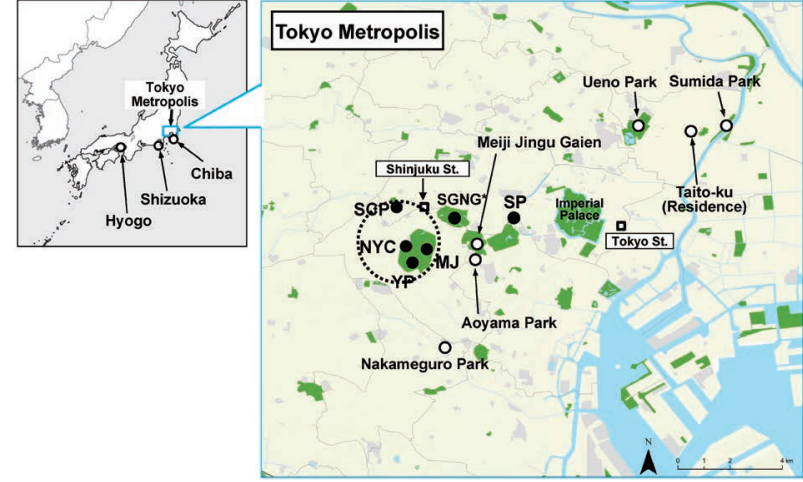

Fig. 3. Map of the vicinity of Tokyo Metropolis showing locations where dengue virus (DENV) transmission was suspected during dengue outbreak in 2014. At the six locations (closed circles) among these, mosquito collections were carried out in this study. Open circles describe locations where DENV transmission was suspected but mosquito survey was not performed. Shinjuku Gyoen National Garden (SGNG)* was not a suspected location of DENV transmission, but mosquito collection was carried out. Abbreviation of the collection sites is described in the text. This figure was from Kobayashi and Murota et al. (2018).

散布による成虫駆除の実施を決定した代々木公園（YP）で は, 8 分間人囮法により合計で雌 36 頭と雄 19 頭が捕集され, 翌29日は雌15頭（Table 4）と雄3頭（Table 5）がそれぞれ
捕集された。代々木公園では続く9月 4 日にも捕集調査を行 い，雌412頭と雄85頭がそれぞれ捕集された（Table 4, Table 5）。そのから 10 月下旬まで公園の一部が閉鎖されること になった。同様に, 新宿中央公園 (SCP), 明治神宮 (MJ), 国立オリンピック記念青少年総合センター（NYC）および 外濠公園（SP）においても8月下旬から9月中旬にかけて蚊 の捕集を行った（Table 4, Table 5). 一方, 新宿御苑（SGNG） では患者発生の報告はなく, 推定感染地とはみなされていな かったが，代々木公園と地理的に近いことから，9月7日か ら10月17日まで環境庁が独自に閉園を決定した。その間 9 月 12 日より 10 月 23 日まで 1 週間毎に, 園内の 10 か所で $\mathrm{CO}_{2}$ トラップ（CDC型ドライアイストラップ）による蚊の捕集 が行われた（Table 4, Table 5).

ヒトスジシマカは卵のステージで越冬することが知られて いる. また，デングウイルスの経卵伝搬も知られていること から, 翌春に越冬から覚醒した幼虫や成虫にウイルスが受け 継がれる可能性を検討するために，新宿中央公園および新宿 御苑においては翌2015年4月20日に幼虫の捕集を行った。得 られた幼虫は飼育室で羽化させた成虫で種を同定し，すべ ての個体をウイルス検出に供した．新宿中央公園からは幼虫 135頭（羽化後に雌 66 頭，雄 69 頭と同定), 新宿御苑からは幼 虫1頭（雌1頭）のみがそれぞれ採取された（Table 4, Table 5).

捕集したヒトスジシマカからのウイルス検出と系統解析 東京都内の公園 6か所から得られた雌2,298頭および雄956

Table 4. Result of detection and isolation of DENV from female Aedes albopictus mosquitoes collected in Tokyo Metropolis in 2014 and 2015.

\begin{tabular}{|c|c|c|c|c|c|c|}
\hline \multirow[b]{2}{*}{ Mosquito collection sites } & & & \multirow{2}{*}{$\begin{array}{l}\text { No. mosquitoes } \\
\text { tested }\end{array}$} & \multirow{2}{*}{$\begin{array}{l}\text { No. pools } \\
\text { tested }\end{array}$} & \multicolumn{2}{|c|}{ No. DENV-positive pools } \\
\hline & \multicolumn{2}{|c|}{ Collection date } & & & $\begin{array}{l}\text { Virus-gene detected } \\
\quad\left(\mathrm{MIR}^{\dagger}\right)\end{array}$ & $\begin{array}{c}\text { Virus } \\
\text { isolated }\end{array}$ \\
\hline \multirow[t]{3}{*}{ Yoyogi Park (YP) } & August 28 & 2014 & 36 & 2 & 0 & 0 \\
\hline & August 29 & 2014 & 15 & 1 & $1(66.7)$ & $\mathrm{NT}^{\ddagger}$ \\
\hline & September 4 & 2014 & 412 & 21 & $13(31.6)$ & 9 \\
\hline \multirow[t]{4}{*}{ Shinjuku Central Park (SCP) } & September 5 & 2014 & 422 & 21 & $6(14.2)$ & 1 \\
\hline & September 8 & 2014 & 32 & 2 & 0 & 0 \\
\hline & September 19 & 2014 & 89 & 4 & $1(11.2)$ & 1 \\
\hline & April 20* & 2015 & 66 & 6 & 0 & 0 \\
\hline \multirow[t]{2}{*}{ Meiji Jingu (MJ) } & September 5 & 2014 & 241 & 12 & $6(24.9)$ & 4 \\
\hline & September 8 & 2014 & 11 & 1 & 0 & 0 \\
\hline \multirow{2}{*}{$\begin{array}{l}\text { National Olympics Memorial } \\
\text { Youth Center (NYC) }\end{array}$} & August 29 & 2014 & 46 & 2 & $1(21.7)$ & NT \\
\hline & September 4 & 2014 & 78 & 4 & $1(12.8)$ & 1 \\
\hline Sotobori Park (SP) & September 9 & 2014 & 71 & 4 & 0 & 0 \\
\hline \multirow{6}{*}{$\begin{array}{l}\text { Shinjuku Gyoen National Garden } \\
\text { (SGNG) }\end{array}$} & September 12 & 2014 & 296 & 15 & $10(33.8)$ & NT \\
\hline & September 19 & 2014 & 424 & 15 & $9(21.2)$ & NT \\
\hline & September 26 & 2014 & 37 & 7 & $1(27.0)$ & NT \\
\hline & October 3 & 2014 & 7 & 2 & 0 & NT \\
\hline & October 8 & 2014 & 14 & 4 & 0 & 0 \\
\hline & April 20* & 2015 & 1 & 1 & 0 & 0 \\
\hline Total & & & 2,298 & 124 & 49 & 16 \\
\hline
\end{tabular}

* Larvae collected were maintained in the laboratory and emerged adults were tested.

${ }^{\dagger}$ MIR is defined as (number of DENV-positive pools/number of mosquitoes tested) $\times 1,000$.

NT is not tested.

This table was modified from Kobayashi and Murota et al. (2018). 
Table 5. Result of detection and isolation of DENV from male Aedes albopictus mosquitoes collected in Tokyo Metropolis in 2014 and 2015.

\begin{tabular}{|c|c|c|c|c|c|c|}
\hline \multirow[b]{2}{*}{ Mosquito collection sites } & \multirow{2}{*}{\multicolumn{2}{|c|}{ Collection date }} & \multirow{2}{*}{$\begin{array}{l}\text { No. mosquitoes } \\
\text { tested }\end{array}$} & \multirow{2}{*}{$\begin{array}{l}\text { No. pools } \\
\text { tested }\end{array}$} & \multicolumn{2}{|c|}{ No. DENV-positive pools } \\
\hline & & & & & Virus-gene detected & Virus \\
\hline \multirow[t]{3}{*}{ Yoyogi Park (YP) } & August 28 & 2014 & 19 & 1 & 0 & 0 \\
\hline & August 29 & 2014 & 3 & 1 & 0 & 0 \\
\hline & September 4 & 2014 & 85 & 3 & 0 & 0 \\
\hline \multirow[t]{3}{*}{ Shinjuku Central Park (SCP) } & September 5 & 2014 & 568 & 19 & 0 & 0 \\
\hline & September 8 & 2014 & 23 & 1 & 0 & 0 \\
\hline & April 20* & 2015 & 69 & 5 & 0 & 0 \\
\hline \multirow[t]{2}{*}{ Meiji Jingu (MJ) } & September 5 & 2014 & 34 & 1 & 0 & 0 \\
\hline & September 8 & 2014 & 1 & 1 & 0 & 0 \\
\hline \multirow{2}{*}{$\begin{array}{l}\text { National Olympics Memorial } \\
\text { Youth Center (NYC) }\end{array}$} & August 29 & 2014 & 1 & 1 & 0 & 0 \\
\hline & September 4 & 2014 & 4 & 1 & 0 & 0 \\
\hline Sotobori Park (SP) & September 9 & 2014 & 34 & 1 & 0 & 0 \\
\hline \multirow{6}{*}{$\begin{array}{l}\text { Shinjuku Gyoen National Garden } \\
\text { (SGNG) }\end{array}$} & September 12 & 2014 & 56 & $\mathrm{NT}^{\ddagger}$ & - & - \\
\hline & September 19 & 2014 & 55 & $\mathrm{NT}^{\ddagger}$ & - & - \\
\hline & September 26 & 2014 & 2 & $\mathrm{NT}^{\ddagger}$ & - & - \\
\hline & October 3 & 2014 & 1 & $\mathrm{NT}^{\ddagger}$ & - & - \\
\hline & October 8 & 2014 & 1 & 1 & 0 & 0 \\
\hline & April 20* & 2015 & 0 & 0 & - & \\
\hline Total & & & 956 & 35 & 0 & - \\
\hline
\end{tabular}

* Larvae collected were maintained in the laboratory and emerged adults were tested.

${ }^{\dagger}$ MIR is defined as (number of DENV-positive pools/number of mosquitoes tested) $\times 1,000$.

NT is not tested.

This table was modified from Kobayashi and Murota et al. (2018).

頭をそれぞれ124プールと35プールに集約し，それぞれの 蚊乳剂から抽出した全RNAに対してデングウイルス特異的 RT-PCRおよびTaqMan assayを行った。 また，同時に蚊乳剤 をC6/36細胞およびVero細胞に接種することでウイルス分 離を試みた（Kobayashi and Murota et al., 2018）。その結果, 雌 49 プールがデングウイルス遺伝子陽性（血清型1型）と 判定された．陽性蚊が検出された推定感染地の最低陽性蚊 数（Minimum infection rate, MIR: 1 プール中に最低でも1頭 の陽性蚊がいると仮定した場合の 1,000 頭中の陽性蚊数）は 11.2-66.7 と算出され，ヒトスジシマカのデングウイルス保有 率は極女て高いことが確認された（Table 4)。 また，外濠公 園以外の調查地の 6 地点中 5 地点で, 9 中旬から下旬までウ イルス保有蚊が存在していたことも明らかになった。さら に，陽性と判定されたプールのうち 16 プールからデングウ イルスの分離に成功した。一方，2015年4月に捕集された幼 虫（羽化成虫を検査に用いた）からはウイルスは検出され なかった（Table 4, Table 5). 2015年4月の都内の公園からは, 限られた数の幼虫しか採取できなかったが, ウイルスの垂直 伝播も越冬の可能性も著しく低いと考えてよいと思われた。

都内の 4 つの公園（YP, SCP, MJ, NYC）の捕集蚊からはウ イルス分離株が得られ，そのエンベロープ（E）遺伝子（約 1,500 塩基）の塩基配列を解析した結果，国内感染第一例目 （GenBank Accession No. LC002828）を含む，都内で感染した 患者由来のデングウイルス 1 型の遺伝子配列と $99 \%$ 以上の塩 基配列同一性が認められた (結果は省略)。E領域の系統樹 解析から，2014年国内流行株はデング 1 型の遺伝子型I型ウ
イルスであり, 由来の異なる 2 つウイルス（おそらく東南 アジア由来と台湾由来）が国内で流行し，少なくとも東京都 内では, 同一のデングウイルスが流行していたと推察され た（Fig. 4).さらに，次世代シークエンサー（NGS）による 配列解析を行い，11株のコード領域全長の配列（約 10,000塩 基）を決定した。 それらの塩基配列を上述した国内感染者由 来デングウイルスの配列と比較したところ，塩基置換が認め られた株が 5 株, うちアミノ酸置換が生じたものが 2 株得ら れた. 本結果から蚊体内でウイルス遺伝子に何らかの変異が 起きている可能性が示唆された（Kobayashi and Murota et al., 2018).

\section{ヒトスジシマカのデングウイルス増殖能}

ヒトスジシマカのデングウイルス媒介能を評価するため に，デングウイルスを蚁に経口的に感染させた．ヒトスジシ マカは, IKT系統（2010年川崎市生田地区で捕集）, EBN系 統（2011年神奈川県海老名市捕集）およびHCM系統（2012 年ベトナム・ホーチミン市捕集）を感染実験に用いた。ネッ タイシマカAe. aegypti (L.) LBN系統は, 2010年フィリピ ン・ロスバニョス市で捕集された雌成虫から採卵し，その 後実験室内で維持された系統である. デングウイルス 1 型 （DENV1）は, タイ・バンコク市からの帰国者の血清から 分離された株（D1 11-120), デングウイルス2型（DENV2） は，インドネシア・バリ島からの帰国者血清から分離された 株（D2 11-122/1）である（いずれも国立感染症研究所ウイル

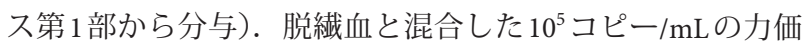




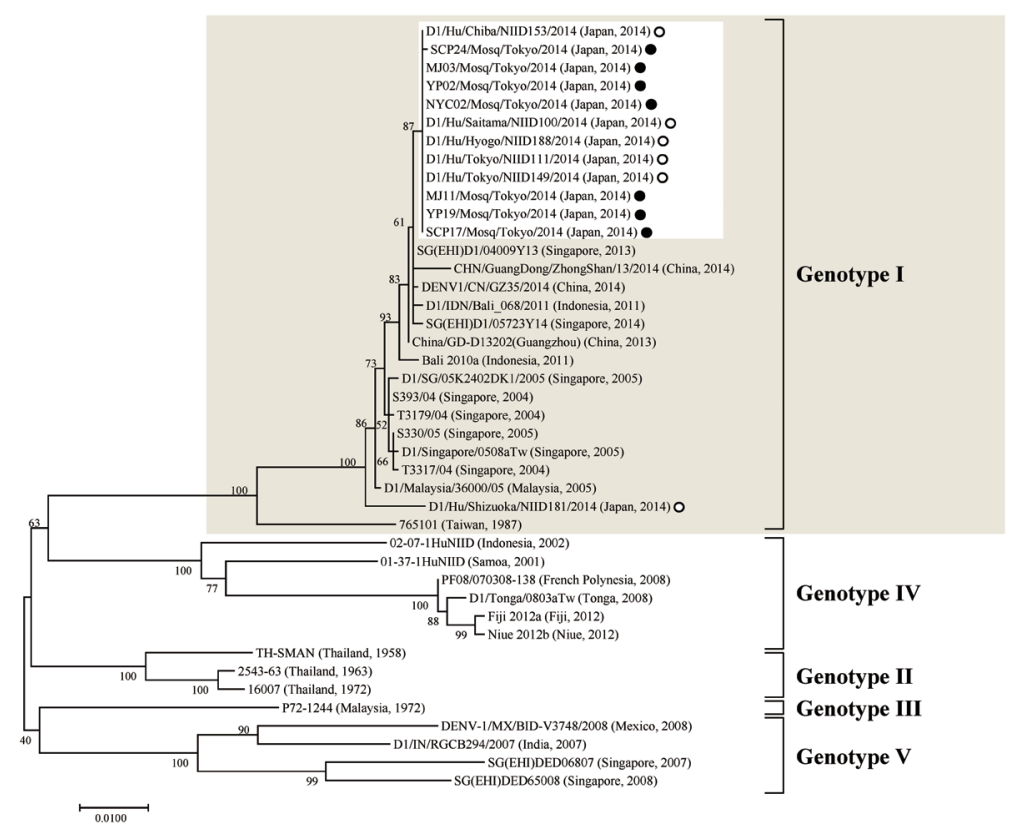

Fig. 4. Phylogenetic analysis of dengue virus (DENV1) sequences derived from Ae. albopictus collected in Tokyo Metropolis Japan, in 2014, among previously described strain/isolates of DENV1 based on the E gene sequences. Phylogenetic analysis was performed by maximum likelihood method based on the E gene of selected DENV1 strains including genotype I-V. The percentages of 1,000 bootstrap replication were indicated at the nodes. The DENV1 strains derived from Ae. albopictus in this study are indicated with closed circles. Moreover, six in Tokyo and one in Chiba from the patients of autochthonous dengue outbreak in Japan in 2014 are indicated with open circles. This figure was from Kobayashi and Murota et al. (2018).

Table 6. Susceptibility of foreign and domestic Aedes aegypti and Aedes albopictus to dengue virus infection. (data from Sasaki et al., 2015).

\begin{tabular}{lcccc}
\hline \hline \multicolumn{1}{c}{ Days post-infection of 21-25 days } & \multicolumn{2}{c}{ Tissue } \\
\hline \multicolumn{1}{c}{ Species and strain } & Dengue virus & Salivary grand & Midgut & Carcass \\
\hline \multirow{2}{*}{ Aedes aegypti LBN strain } & Type 1 & 6 & 6 & 6 \\
& Type 2 & 1 & 1 & 6 \\
\hline \multirow{2}{*}{ Aedes albopictus IKT strain } & Type 1 & 6 & 6 & 6 \\
EBN strain & Type 2 & 6 & 6 & 6 \\
HCM strain & Type 1 & 5 & 6 & 6 \\
& Type 2 & 6 & 6 & 6 \\
\hline
\end{tabular}

$6>10,000 \quad 5 \quad 5,000-10,000 \quad 4 \quad 1,000-5,000$

This table was modified from Sasaki et al. (2015).

のウイルス液を人工膜吸血法により経口的に蚊に摂取させ, その後，感染蚊をインキュベーター内で約20日間維持した. 感染21-25日後にそれぞれ解剖し，SYBR Green法（Callahan JD et al. 変法) でデングウイルスRNAを検出し，免疫蛍光抗 体法によりウイルスの局在を観察した（Sasaki et al., 2015）.

本邦産ヒトスジシマカIKT系統では, DENV1の感染21-25 日後の唾液腺, 中腸, その他の組織から 10,000コピー/組織 (以下, 組織当たりのコピー数として省略)）以上が検出され た（Table 6).一方，DENV2は唾液腺では500コピー以下し か検出されなかったが，中腸およびその他の組織においては 10,000コピー以上が検出された. EBN系統では, DENV1は 唾液腺, 中腸, その他の組織において 10,000 コピー以上が検 出され, DENV2でも5,000-10,000コピーが唾液腺から検出さ れた。 ホーチミン HCM系統は, DENV1の感染 21 日から 23
日後に唾液腺，中腸，その他の組織において 10,000 コピー以 上が検出されたが，DENV2は，唾液腺において1,000-5,000 コピー, 中腸およびその他の組織においては10,000コピー 以上が検出された。 フィリピンで捕集されたネッタイシマ 力 LBN系統においても, DENV1は唾液腺, 中腸, その他の 組織から 10,000コピー以上が検出された。一方, DENV2は, ネッタイシマカLBN系統のいずれの組織においても500コ ピー以下しか検出されず，増殖しなかったと判定された。

本研究に用いた国内抢よび外国産ヒトスジシマカでは DENV1の高い増殖性が認められたが，一方で, DENV2は, DENV1に比べて増殖性が低く, 特にLBN系統ネッタイシマ カではその増殖は非常に低いレベルであった. ヒトスジシマ カのデングウイルス感受性は系統によって感受性が異なるこ とが示唆されたが, 本研究に供した本邦産ヒトスジシマカに 
Table 7. Mammalian hosts for Aedes albopictus and Culex pipiens group collected from the residential areas during the mosquito seasons of 2003-2007.

\begin{tabular}{|c|c|c|c|}
\hline \multirow{2}{*}{ Mammalian species } & Ae. albopictus ${ }^{b}$ & Cx.p.pallens & Cx.p. form molestus \\
\hline & No. $(\%)$ & No. (\%) & No. $(\%)$ \\
\hline Human (Homo sapiens) & $75(68.8)$ & $29(43.9)$ & $19(82.6)$ \\
\hline Cat (Felis catus) & $9(8.3)$ & $12(18.2)$ & $1(4.3)$ \\
\hline Dog (Canis familiaris) & 0 & $15(15.2)$ & $1(4.3)$ \\
\hline House mouse (Mus musculus) & $16(14.7)$ & $4(6.1)$ & $4(6.0)$ \\
\hline Brown rat (Rattus norvegicus) & 0 & $1(1.5)$ & $1(1.5)$ \\
\hline Cow (Bos taurus) & $9(8.3)$ & $1(1.5)$ & $1(1.5)$ \\
\hline Pig (Sus scrofa $)^{a}$ & 0 & $1(1.5)$ & $1(1.5)$ \\
\hline Unidentifiable & 0 & $8(12.1)$ & $2(8.7)$ \\
\hline Total mammalian & $109(100)$ & $66(100)$ & $23(100)$ \\
\hline
\end{tabular}

${ }^{a}$ Pig includes wild bore; they were not identified from the sequence information available in the GenBank database.

${ }^{b}$ Includes seven specimens which fed on two different mammalian and other species ( 2 fed on human and house mouse, 2 fed on human and cattle, 1 fed on house mouse and cattle, 1 fed on cat and house mouse and 1 fed on human and reptile).

Table 8. Avian hosts for Aedes albopictus and Culex pipiens group collected from the residential areas during the mosquito seasons of 2003-2007.

\begin{tabular}{|c|c|c|c|}
\hline \multirow{2}{*}{ Avian species } & Ae. Albopictus & CX.p.pallens & Cx.p. form molestus \\
\hline & No. $(\%)$ & No. $(\%)$ & No. $(\%)$ \\
\hline Tree sparrow (Passer montanus) ${ }^{a}$ & 0 & $43(51.8)$ & $7(30.4)$ \\
\hline Ducks $(\text { Anas spp. })^{b}$ & $10(76.9)$ & $28(33.7)$ & $12(52.2)$ \\
\hline Great tit (Parus major) & 0 & $2(2.4)$ & $1(4.3)$ \\
\hline Jungle crow (Corvus macrorhynchos) & 0 & $2^{c}(2.4)$ & 0 \\
\hline White-cheeked starling (Sturnus cineraceus) & 0 & $1(1.2)$ & 0 \\
\hline Oriental greenfinch (Carduelis sinica) & 0 & $1(1.2)$ & 0 \\
\hline Japanese white-eye (Zosterops japonicus) & 0 & $1(1.2)$ & 0 \\
\hline Chinese little bittern (Ixobrychus sinensis) & 0 & $1(1.2)$ & $0(4.3)$ \\
\hline Domestic canary (Serinus canaria) & 0 & $1(1.2)$ & 0 \\
\hline Shrikes (Lanius sp.) & 0 & $1^{d}(1.2)$ & 0 \\
\hline Brown-eared bulbul (Hypsipetes amaurotis) & $2(15.4)$ & 0 & 0 \\
\hline Unidentifiable & $1(7.7)$ & $2(2.4)$ & $2(8.7)$ \\
\hline Total avian & $13(100)$ & $83(100)$ & $23(100)$ \\
\hline
\end{tabular}

${ }^{a}$ Tree sparrow includes Russet sparrow (P. rutilans)

${ }^{b}$ Ducks include spot-billed duck (A. poecilorhyncha), mallard (A. platyrhynchos) and domestic duck (A. platyrhynchos var. domesticus); they were not identified from the sequence information available in the GenBank database.

${ }^{c}$ Jungle crow includes one specimen having $85 \%$ sequence identity.

${ }^{d}$ One specimen of $C x$. p. pallens showed $93 \%$ sequence identity to bull-headed shrike (L. bucephalus).

おいては，ある程度の増殖性が認められたと言える。さらに 多くの系統を評価する必要があるが，少なくともDENV1に 対しては，本邦産ヒトスジシマカの多くの集団は感受性であ ると推察された。本結果より，国内にデング熱が侵入した場 合には，国内に分布するヒトスジシマカが媒介する小規模な アウトブレイクが起こる可能性は十分あることが示唆され た.

\section{ヒトスジシマカの吸血嗜好性と吸血源動物}

2003年から 2007 年にかけて，国内の主に住宅地で捕獲さ れたヒトスジシマカ 114 頭, アカイエカ種群 177 頭の吸血蚊 を材料として吸血源動物の同定を行った。吸血蚊の体内に 残っている動物由来血液のDNAを哺乳類検出用, 鳥類検出 用のそれぞれ特異的プライマー，および哺乳類・鳥類共通プ ライマーを用いて PCRを行い，ダイレクトシークエンスに より配列を決定した（Sawabe et al., 2010）。その結果，ヒトス
ジシマカはヒト Homo sapiens (Linnaeus), ネコ Felis silvestris catus Linnaeus, 1758，ネズミMus musculus molossinusまたは Rattus norvegicus (Berkenhout), 力モ類Anas spp. に加えてア カガエル属Rana sp. やヒキガエル属Bufo sp. からも吸血して いたことが明らかになった（Table 7, Table 8). ヒトスジシマ 力は待ち伏せ型の吸血行動を示し，昼夜を問わず近づいて来 た動物をえり好みせずに吸血源としているため，地上を徘徊 する多様な動物が吸血源となっていると思われる。なお，首 都圏で捕集されたヒトスジシマカは, 検出された哺乳動物の 血液の中でも特にヒトを吸血した割合が明らかに高かった (Table 7). 他方, アカイエカ群Culex pipiens groupは Kasai et al. (2008) のマルチプレックス PCRにより，アカイエカ 134 頭，チカイエカ 41 頭，両者の交雑個体と思われる2頭に判別 された. アカイエカとチカイエカはともに，ほ乳類と鳥類を ほぼ同数吸血して抢り，その嗜好性に有意な差は認められ なかった（ $\chi 2$ test, $P>0.4 ）$ (Fig. 5). また, アカイエカは 17 種 


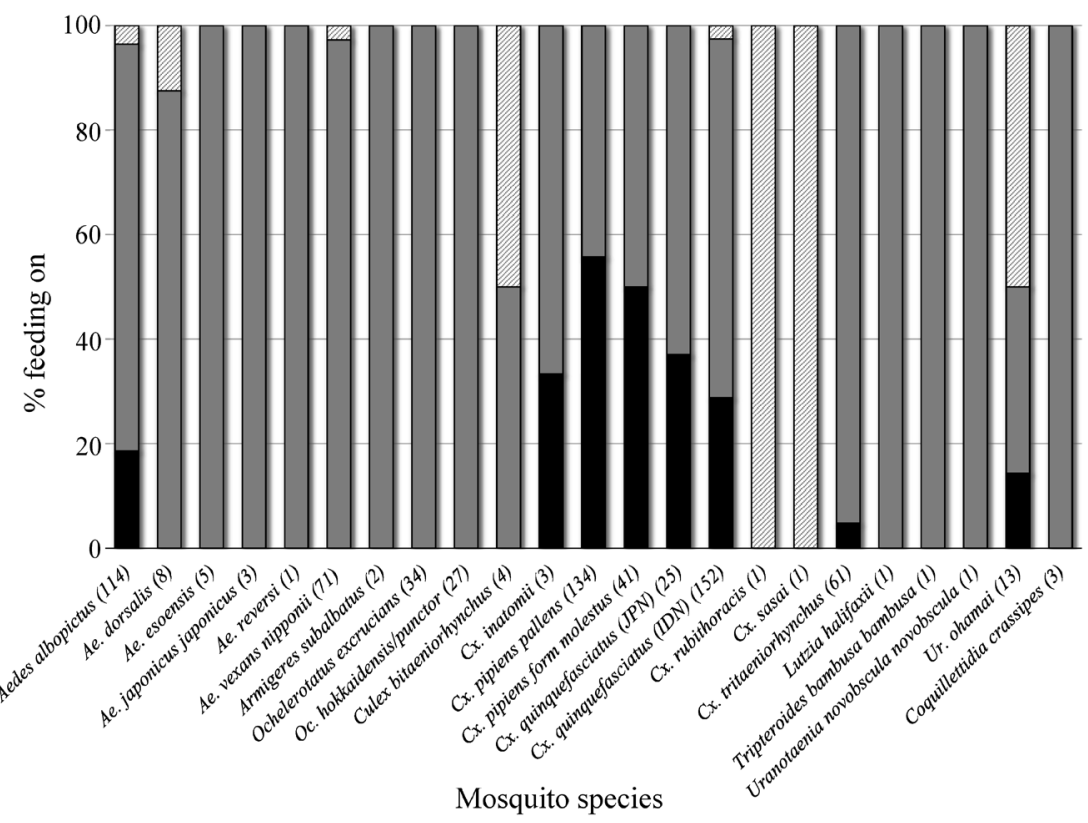

Fig. 5. Blood-feeding patterns of a total of 706 mosquitoes of 23 species from eight genera. Mosquitoes blood-fed on avian blood (black bar), mammalian blood (gray bar) and others contains amphibians and reptiles (left hatched bar). The number in parentheses indicates the number of mosquitoes tested.

類の動物を利用したのに対し, チカイエカは 11 種類であっ たのは，活動範囲の広さによる差と思われる（Table 7, Table 8). 両種の主要な吸血源動物種は, 鳥類ではスズメPasser montanus Linnaeus とカモ類（Table 7)，ほ乳類ではヒト，ネ コ, イヌ Canis lupus familiaris（Linnaeus, 1758）であり（Table 8), 両者の吸血嗜好に大きな差異はなかった.

上述したヒトスジシマカおよびアカイエカ種群を含む 8 属23種, 合計706頭の吸血嗜好性を比較した（Fig. 5).こ の中で鳥類を吸血していた蚊は, イエカ属の5種, ヒトス ジシマカおよびシロオビカニアナチビカUranotaenia ohamai Tanaka, Mizusawa and Saugstatであった. 特にアカイエカ種 群の3 種 (アカイエカ, チカイエカ, ネッタイイエカCx. quinquefasciatus Say) とイナトミシオカ Cx. inatomii Kamimura and Wadaの鳥類嗜好性は高く, 哺乳類とほぼ同数に近かっ た. 調査した個体数は少なかったが, カラッイエカ $C x$. bitaeniorhynchus Gilesやシロオビカニアナチビカが両生・爬 虫類を吸血しており，上述したように，低い割合ではあった がヒトスジシマカやセスジヤブカAe. dorsalis (Meigen), キ ンイロヤブカAe. vexsans nipponii (Meigen), ネッタイイエカ にもその傾向が見られた.

これらの結果から, ヒトスジシマカはヒト吸血嗜好性が高 いものの, その他多くの種類の動物も日和見的に吸血するこ とから, デング熱等の感染症の流行は大規模にはなり難いと 推察される. 一方でアカイエカ種群は鳥類と哺乳類（主にヒ ト）を同程度に吸血し得ることから, ウエストナイルウイル スに代表される鳥類由来のウイルスを哺乳類に橋渡しするブ リッジベクターとして貢献することが予想される.

\section{媒介蚊の対策}

著者らは, ウエストナイル熱の国内流行が懸念された 2003年から全国的な蚊相調査を開始し，アカイエカ種群と ヒトスジシマカをはじめ, 国内におけるウエストナイルウ イルスの潜在的媒介蚊を約 10 種類選別し，それらを対象と
した媒介蚊対策ガイドラインを作成した（国立感染症研究 所，2003）。さらに，チクングニア熱の世界的な大流行を受 けて，2009年11月にヒトスジシマカに対象を絞った対策ガ イドラインを作成したが（国立感染症研究所，2009）, これ まで, 国内の野外で殺虫剂を使用する事例はほとんどなかっ たことから，具体的には幼虫発生源の撤去や成虫の潜み場所 の清掃等の物理的対応に留めた. 2014年 8 月に約 70 年ぶりの デング熱国内感染例を経験することになったが, 推定感染地 とされた場所のほとんどで殺虫剤が散布され（関ら，2015; Tanikawa et al., 2015), 化学的防除が推奨される場面があるこ とが自治体や国民の間で徐々に認識されるようになった. 事 実, 2019年の沖縄県と京都府・奈良県で発生したデング熱 の国内感染例（沖縄県の症例は疑い例とされた）では, 各自 治体によって推定感染地となった公園や民家周辺で殺虫剂に よる成虫駆除が実施された。

著者らは，2014年4月に「デング熱媒介蚊対策に関するガ イドライン(案)」を作成し，デング熱の国内流行をある程度 予測して準備していたとは言え, 実際には, 推定感染地での 媒介蚊対策に混乱が生じた現場があったことは経験不足の一 言に尽きる. 推定感染地の多くでは主にエトフェンプロッ クスあるいはフェノトリンが散布され, 茂みの中に潜む成 虫に対しては，炭酸ガス製剂が使用されたが（関ら，2015; Tanikawa et al., 2015), 散布後の効果判定で, 効果が低かった 場所があったことが確認された. 著者らはそれ以降, 特に, 薬剤の種類と剂型, 薬剤の散布方法, 効果判定の方法に関し て, 現在までに複数回の野外実地試験を実施し, 新たな情報 を蓄積することに努めた。試験した殺虫剂はすべて, 屋内で 使用する上では十分な殺虫効果があると判断されるものであ るが, 野外で使用する場合は, 散布場所の植生や地形, 風向 や風速, 気温等の様々な環境条件を考慮して, 薬剤の種類と 剂型を選び，かつ適切な機材と方法で散布することが不可欠 であると結論した (Minagawa et al., in preparation)。これらの 結果と 2014 年の媒介蚊対策で得られた知見を加え，2019年 4 
月に「デング熱・チクングニア熱・ジカウイルス感染症等の 媒介蚊対策＜緊急時の対応マニュアル＞」（国立感染症研究 所，2019）を作成した．本マニュアルは，2015年に平常時の 対応を中心にした「デング熱・チクングニア熱等蚊媒介感染 症の対応・対策の手引き地方公共団体向け」（国立感染症研 究所，2015）の内容から，緊急時の媒介蚊対策に焦点を当て て解説し, さらに, 近年, 繰り返し国内に侵入しているネッ タイシマカにも言及したものである.

\section{おわりに}

近年，節足動物が媒介する新興・再興感染症は世界各地で 流行し，我が国においても，本稿で紹介した八工と蚊が媒介 する感染症のみならず, 様々な種類の感染症が発生している 状況にある．このように，著者らはこれまでにいくつもの節 足動物媒介感染症の流行に直面し, その都度適切な対策を実 施するよう努めてきた。本稿で鳥インフルエンザとデング熱 の国内感染例への対応を例に紹介したが，それ以外の節足動 物媒介感染症への対応においても，まず感染症の流行地でべ クターと思われる節足動物を採材することから始め, それら から病原体を検出すると同時に，ベクター自身の生物学的特 徵や野外での生態学的動態を調查し，理解することが効果的 な対策に繋がると考えている．日本がすでにデング熱が毎年 流行しても不思議ではない国と世界中が認識している現状を 理解し, さらに今後も起きるであろう様々な節足動物感染症 の国内発生に備えなければならない。

\section{謝辞}

幸いにも私は，これら一連の研究が一貫して行える研究機 関に所属し，身近にいる専門家の方々と協力して研究に携わ る幸運に恵まれました．国立感染症研究所昆虫医科学部の 方々, 実験の補助をしていただいた大学院生および学部学生 諸君, 関連の自治体担当者の方々, ならびに所外の協力研究 者の方々のご支援とご協力の扔かげで, 多少なりとも節足動 物媒介感染症対策に貢献することができました，また，野外 調查や野外実地試験を行うにあたり, 国内外の協力研究者の 方々，公園・施設管理者ならびに自治体担当者の方々のご理 解とご協力をいただいたことにも深く感謝いたします。個人 のお名前は省略させていただきますが，ご協力いただいた関 係者すべての方々にこの場をお借りして深くお礼申し上げま す. 最後に, これらの研究成果が, 今後の節足動物媒介感染 症対策の一助になれば大変うれしく思います。

\section{文献}

安居院宣昭. 1998. 腸管出血性大腸菌O157保有八工類に 関する全国調査. 病原体検出情報IASR, 19(6). [accessed December 26, 2019]. http://idsc.nih.go.jp/iasr/19/220/dj2202. html

Arima, Y., Matsui, T., Shimada, T., Ishikane, M., Kawabata, K., Sunagawa, T., Kinoshita, H., Takasaki, T., Tsuda, Y., Sawabe, K. and Oishi, K. 2014. Ongoing local transmission of dengue in Japan, Augusut to September 2014. Western Pac. Surveill. Response J., 5: 27-29.

Dalla Pozza, G. L., Romi, R. and Severini, C. 1994. Source and spread of Aedes albopictus in the Veneto region of Italy. J. Am. Mosq. Control Assoc., 10: 589-592.

George, C. M., Ahmed, S., Talukder, K. A., Azmi, I. J., Perin, J., Sack, R. B., Sack, D. A., Stine, O. C., Oldja, L., Shahnaij, M.,
Chakraborty, S., Parvin, T., Bhuyian, S. I., Bouwer, E., Zhang, X., Hasan, T. N., Luna, S. J., Akter, F. and Faruque, A. S. 2015. Shigella Infections in household contacts of pediatric shigellosis patients in rural Bangladesh. Emerg. Infect. Dis., 21: 2006-2013.

林 利彦, 澤辺京子. 2016. 岩手県に打ける東日本大震災被 災瓦礫集積場における八工類発生調査（2012年)。衛生動 物, 67: 101-104.

Iwasa, M., Makino, S., Asakura, H., Kobori, H. and Morimoto, Y. 1999. Detection of Escherichia coli O157:H7 from Musca domestica (Diptera: Muscidae) at a cattle farm in Japan. J. Med. Entomol., 36: 108-112.

Khamesipour, F., Lankarani, K. B., Honarvar, B. and Kwent, T. E. 2018. A systematic review of human pathogens carried by the housefly (Musca domestica L.). BMC Public Health, 18: 1049.

Kasai, S., Komagata, O., Tomita, T., Sawabe, K., Tsuda, Y., Kurahashi, H., Ishikawa, T., Motoki, M., Takahashi, T., Tanikawa, T., Yoshida, M., Shinjo, G., Hashimoto, T., Higa, Y. and Kobayashi, M. 2008. PCR-based identification of Culex pipiens complex collected in Japan. Jpn. J. Infect. Dis., 61: 184-191.

Kobayashi, M., Sasaki, T., Saito, N., Tamura, K., Suzuki, K., Watanabe, H. and Agui, N. 1999. Houseflies: not simple mechanical vectors of enterohemorrhagic Escherichia coli O157:H7. Am. J. Trop. Med. Hyg., 61: 625-629.

Kobayashi, D., Murota, K., Fujita, R., Itokawa, K., Kotaki, A., Moi, M. L., Ejiri, H., Maekawa, Y., Ogawa, K., Tsuda, Y., Sasaki, T., Kobayashi, M., Takasaki, T., Isawa, H. and Sawabe, K. 2018. Dengue virus infection in Aedes albopictus during the 2014 autochthonous dengue outbreak in Tokyo Metropolis, Japan. Am. J. Trop. Med. Hyg., 98: 1460-1468.

Kobayashi, M., Komagata, O., Yonejima, M., Maekawa, Y., Hirabayashi, K., Hayashi, T., Nihei, N., Yoshida, M., Tsuda, Y. and Sawabe, K. 2014. Retrospective search for dengue vector mosquito Aedes albopictus in areas visited by a German traveler who contracted dengue in Japan. Int. J. Infect. Dis., 26: 135-137.

Komagata, O., Kasai, S., Kobayashi, M. and Tomita, T. 2007. Insecticide susceptibility of the blowfly, Calliphora nigribarbis Vollenhoven, collected in Yamaguchi Prefecture, Japan. Med. Entomol. Zool., 57: 205-209.

倉橋 弘, 末永 斂. 1997. オオクロバエが秋期に大陸から 日本へ飛来し，繁殖することを推測させる長崎での一観 察. 衛生動物, 48: 55-58.

Kutsuna, S., Kato, Y., Moi, M. L., Kotaki, A., Ota, M., Shinohara, K., Kobayashi, T., Yamamoto, K., Fujiya, Y., Mawatari, M., Sato, T., Kunimatsu, J., Takeshita, N., Hayakawa, K., Kanagawa, S., Takasaki, T. and Ohmagari, N. 2015. Autochthonous dengue fever, Tokyo, Japan, 2014. Emerg. Infect. Dis., 21: 517-520.

国立感染症研究所，2003。 ウエストナイル熱媒介蚊対策に関 するガイドライン. [accessed January 6, 2020]. Available from: https://www.niid.go.jp/niid/ja/wnv/1797-ent/2550-entwnv.html

国立感染症研究所，2009。チクングニヤ熱媒介蚊対策に関す るガイドライン. [accessed January 6, 2020]. Available from: https://www.niid.go.jp/niid/ja/chikungunya-m/1835-ent/2470entguideline.html

国立感染症研究所，2015. デング熱・チクングニア熱等 蚊媒介感染症の対応・対策の手引き地方公共団体向 け. [accessed January 6, 2020]. Available from: http://www. mhlw.go.jp/file/04-Houdouhappyou-10906000-KenkoukyokuKekkakukansenshouka/270428.pdf

国立感染症研究所，2019. デング熱・チクングニア熱・ジカ ウイルス感染症等の媒介蚊対策〈急時の対応マニュアル〉. [accessed January 6, 2020]. Available from: https://www.niid. go.jp/niid/ja/lab/478-ent/8757-2019-04-23-09-18-40.html

Mase, M., Tsukamoto, K., Imada, T., Imai, K., Tanimura, N., Nakamura, K., Yamamoto, Y., Hitomi, T., Kira, T., Nakai, T., Kiso, M., Horimoto, T., Kawaoka, Y. and Yamaguchi, S. 2005. Characterization of $\mathrm{H} 5 \mathrm{~N} 1$ influenza A viruses isolated during the 2003-2004 influenza outbreaks in Japan. Virology, 332: 167-176. 
岡部信彦. 2004. 鳥インフルエンザの流行, 2004年. 病原体 検出情報IASR, 25(11). [accessed January 22, 2019]. http://idsc. nih.go.jp/iasr/25/297/dj2976.html

Qureshi, T., Saeed, A. and Usmanghani, K. 2014. Report: prevalence of shigellosis in three different areas of Karachi. Pak. J. Pharm. Sci., 27: 381-388.

Salamatian, I., Moshaverinia, A., Razmyar, J. and Ghaemi, M. 2019. In vitro Acquisition and Retention of Low-Pathogenic Avian Influenza H9N2 by Musca domestica (Diptera: Muscidae). J. Med. Entomol., tjz175.

Sasaki, T., Kobayashi, M. and Agui, N. 2000. Epidemiological potential of excretion and regurgitation by Musca domestica (Diptera: Muscidae) in the dissemination of Escherichia coli O157: H7 to food. J. Med. Entomol., 37: 945-949.

Sasaki, T., Higa, Y., Bertuso, A. G., Isawa, H., Takasaki, T., Minakawa, N. and Sawabe, K. 2015. Susceptibility of indigenous and transplanted mosquito spp. to dengue virus in Japan. Jpn. J. Infect. Dis., 68: 425-427.

佐々木年則, 星野啓太, 比嘉由紀子, 伊澤晴彦, 小林睦生, 沢辺京子．2010. わが国の都市部における路上生活者よ り採取されたコロモジラミからの Bartonella quintana検出. 病原体検出情報IASR, 31: 354-355.

Sawabe, K., Isawa, H., Hoshino, K., Sasaki, T., Roychoudhury, S., Higa, Y., Kasai, S., Tsuda, Y., Nishiumi, I., Hisai, N., Hamao, S. and Kobayashi, M. 2010. Host-feeding habits of Culex pipiens and Aedes albopictus (Diptera: Culicidae) collected at the urban and suburban residential areas of Japan. J. Med. Entomol., 47: 442-450.

Sawabe, K., Hoshino, K., Isawa, H., Sasaki, T., Hayashi, T., Tsuda, Y., Kurahashi, H., Tanabayashi, K., Hotta, A., Saito, T., Yamada, A. and Kobayashi, M. 2006. Detection and isolation of highly pathogenic $\mathrm{H} 5 \mathrm{~N} 1$ avian influenza A viruses from blow flies collected in the vicinity of an infected poultry farm in Kyoto, Japan, 2004. Am. J. Trop. Med. Hyg., 75: 327-332.

Sawabe, K., Tanabayashi, K., Hotta, A., Isawa, H., Sasaki, T., Yamada, A., Kurahashi, H., Shudo, C. and Kobayashi, M. 2009. Survival of avian H5N1 influenza A viruses in Calliphora nigribarbis (Diptera: Calliphoridae). J. Med. Entomol., 46: 852855.

Sawabe, K., Hoshino, K., Isawa, H., Sasaki, T., Kim, K. S., Hayashi, T., Tsuda, Y., Kurahashi, H. and Kobayashi, M. 2011. Blow flies were likely candidates for transmission of highly pathogenic H5N1 avian influenza virus during the 2004 outbreaks in Japan. Influenza Res. Treat., 2011: 652652.

沢辺京子, 前川芳秀, 小林睦生, 山内 繁, 長島 渡, 奥山 弘幸. 2018. 2017年青森県および北海道南部で実施したヒ トスジシマカ生息調査. 衛生動物, 69, Supplement: 45 .

沢辺京子, 葛西真治, 冨田隆史, 佐々木年則, 小林睦生. 2010. 日本と諸外国のアタマジラミにおける Bartonella quintana 遺伝子保有状況. 病原体検出情報IASR, 31: 355357.

Schmidt-Chanasit, J., Emmerich, P., Tappe, D., Gunther, S., Schmidt, S., Wolff, D., Hentschel, K., Sagebiel, D., Schoneberg, I., Stark, K. and Frank, C. 2014. Autochthonous dengue virus infection in Japan imported into Germany. September 2013. Euro Surveill., 19: 20681.

関 なおみ，岩下裕子，本 涼子，神谷信行，栗田雅行，田 原なるみ, 長谷川道弥, 新開敬行, 林 志直, 貞升健志, 甲斐明美，中島由紀子，渡瀬博俊，上田 隆，前田秀雄， 小林一司, 石崎泰江, 広松恭子. 2015 . 東京都における
デング熱国内感染事例の発生について. 日本公衛誌，62: 238-249.

Subbarao, K., Klimov, A., Katz, J., Regnery, H., Lim, W., Hall, H., Perdue, M., Swayne, D., Bender, C., Huang, J., Hemphill, M., Rowe, T., Shaw, M., Xu, X., Fukuda, K. and Cox, N. 1998. Characterization of an avian influenza A (H5N1) virus isolated from a child with a fatal respiratory illness. Science, 279: 393-396.

Springer, D. and Wuithiranyagool, T. 1986. The discovery and distribution of Aedes albopictus in Harris County, Texas. J. Am. Mosq. Control Assoc., 2: 217-219.

田原雄一郎, 菅野格朗, 川端健人, 石川善大, 田中康次郎, 平尾素一, 公文堅一, 渡辺 護. 2012. 東北被災地におけ る八工類の大発生とその防除. 衛生動物, 63: 71-83.

Takahashi, T., Maeda, K., Suzuki, T., Ishido, A., Shigeoka, T., Tominaga, T., Kamei, T., Honda, M., Ninomiya, D., Sakai, T., Senba, T., Kaneyuki, S., Sakaguchi, S., Satoh, A., Hosokawa, T., Kawabe, Y., Kurihara, S., Izumikawa, K., Kohno, S., Azuma, T., Suemori, K., Yasukawa, M., Mizutani, T., Omatsu, T., Katayama, Y., Miyahara, M., Ijuin, M., Doi, K., Okuda, M., Umeki, K., Saito, T., Fukushima, K., Nakajima, K., Yoshikawa, T., Tani, H., Fukushi, S., Fukuma, A., Ogata, M., Shimojima, M., Nakajima, N., Nagata, N., Katano, H., Fukumoto, H., Sato, Y., Hasegawa, H., Yamagishi, T., Oishi, K., Kurane, I., Morikawa, S. and Saijo, M. 2014. The first identification and retrospective study of Severe Fever with Thrombocytopenia Syndrome in Japan. J. Infect. Dis., 209: 816-827.

Takashima, I., Morita, K., Chiba, M., Hayasaka, D., Sato, T., Takezawa, C., Igarashi, A., Kariwa, H., Yoshimatsu, K., Arikawa, J. and Hashimoto, N. 1997. A case of tick-borne encephalitis in Japan and isolation of the virus. J. Clin. Microbiol., 35: 1943-1947.

Tanaka, K., Mizusawa, K. and Saugstad, E. S. 1979. A revision of the adult and larval mosquitoes of Japan (including the Ryukyu Archipelago and the Ogasawara Islands) and Korea (Diptera: Culicidae). Contrib. Am. Entomol. Inst., 16: 1-987.

Tanikawa, T., Yamauchi, M., Ishihara, S., Tomioka, Y., Kimura, G., Tanaka, K., Suzuki, S., Komagata, O., Tsuda, Y. and Sawabe, K. 2015. Operation note on dengue vector control against Aedes albopictus in Chiba City, Japan, where an autochthonous dengue case was confirmed in September 2014. Med. Entomol. Zool., 61: 31-33.

Tsuda, Y., Hayashi, T., Higa, Y., Hoshino, K., Kasai, S., Tomita, T., Kurahashi, H. and Kobayashi, M. 2009. Dispersal of a blow fly, Calliphora nigribarbis, in relation to the dissemination of highly pathogenic avian influenza virus. Jpn. J. Infect. Dis., 62: 294-297.

Tsuda, Y., Maekawa, Y., Ogawa, K., Itokawa, K., Komagata, O., Sasaki, T., Isawa, H., Tomita, T. and Sawabe, K. 2016. Biting density and distribution of Aedes albopictus during the September 2014 outbreak of dengue fever in Yoyogi Park and the vicinity in Tokyo Metropolis, Japan. Jpn. J. Infect. Dis., 69: 1-5.

冨田隆史，小林睦生. 2007. 高病原性鳥インフルエンザとク ロバエとの関わり (3) 鷄の研究, 木香書房, 967: 36-39.

World Health Organization. 2019. Fact sheet, Dengue and severe dengue [accessed November 4, 2019]. Available from: https:// www.who.int/en/news-room/fact-sheets/detail/dengue-andsevere-dengue

Yuen, K. Y., Chan, P. K., Peiris, M., Tsang, D. N., Que, T. L., Shortridge, K. F., Cheung, P. T., To, W. K., Ho, E. T., Sung, R. and Cheng, A. F. 1998. Clinical features and rapid viral diagnosis of human disease associated with avian influenza A H5N1 virus. Lancet, 351: 467-471. 